\title{
URBAN MUSLIM YOUTH, PENGAJIAN COMMUNITIES AND SOCIAL MEDIA: FRAGMENTATION OF RELIGIOUS AUTHORITIES IN INDONESIA
}

\author{
Eko Saputra \\ Pascsarjana UIN Sunan Kalijaga Yogyakarta \\ Jl. Laksda Adisucipto, Sleman, Yogyakarta \\ Email:eko322590@gmail.com \\ Dony Arung Triantoro \\ UIN Sultan Syarif Kasim Riau \\ Jl. H.R Soebrantas KM. 12.5, Pekanbaru, Riau \\ Email: arungdony73@gmail.com \\ Ardiansyah \\ Sekolah Tinggi Agama Islam YPIQ Baubau \\ Jl. Sipanjonga, Baubau, Sulawesi Tenggara \\ Email:ansyah_ardi2828@yahoo.co.id
}

Article received August 29 ${ }^{\text {th }}, 2021$; Article revised September $24^{\text {th }}, 2021$; Article approved October 22 ${ }^{\text {th }}, 2021$

\begin{abstract}
Departing from a thesis that states the development of communication technology encourages religious practices among Muslim communities in general, this paper seeks to discuss the fragmentation of religious authority among Muslim youth in Indonesia. The research was conducted through field research. The data were taken from interviews, observation, and documentation. This research showed that the fragmentation of religious authority among muslim youth is motivated by the proliferation of pengajian in Indonesian cities and the use of social media in disseminating da'wah. This research also revealed the involvement of the Indonesian largest da'wah communities that implement youth popular culture in performing pengajian by young ustadz idolized by the young generation. Besides, they also used online media, Youtube and Instagram, to promote their da'wah and even used it as a disseminating media. Hence, this opens up opportunities and facilitates the young generation to instantly gain religious insight without visiting an ustadz or ulama and without becoming a student in an Islamic boarding school.
\end{abstract}

Keywords: fragmentation of religious, pengajian communities, social media

\section{INTRODUCTION}

$\mathrm{T}$ The fragmentation of Indonesian religious authority is a part of Islam global phenomenon instead of a typical one. Muhammad Qosim Zaman (2002) in his study has described how fragmentation has occurred since the time of classical Islamic traditions such as the case of Sunni and Shia, Islamic law mazhab, and the claims of several scientists (hadith, fiqh, theology, and linguistics) in interpreting the primary books of Islam. At its peak, Zaman (2002) described the fragmentation that occurs among Deobandi Ulama in South Asia.

When discussing the discourse on the fragmentation of religious authority, the scholars relate it to the emergence and development of communication technology media such as television, radio, print media, CD-DVD, and the internet. Brayen S. Turner (2007), (Dale Eichelman and Anderson (2003), for instance, they argued that the development of communication technology has fragmented religious authority. In turn, it encourages the emergence of new religious actors without a religious education background. More specifically, religious claims are no longer monopolized by traditional religious authorities or so-called ulama. Z. Zulkifli, (2013) explains "religious authority is indeed pluralized. This is because religious authority in Islam is based on recognition and support." 
Generally, regarding the above fragmentation, there are two groups of religious authorities that are observable in Muslim society. First, the traditional religious authority or known as the ulama (religious scholar) (Nurlaelawati \& Muhrisun, 2018; Suhadi \& Suseno, 2018). This group consisted of people with well-recognized religious abilities in Islamic religious education, such as Islamic boarding schools and universities. With this education, they can access the sources of classical Islamic books and master the Arabic language.

Second, new religious authorities, namely new religious actors or in academic studies known as religious entrepreneur. They are considered not to have a strong religious education background. It could be because they gain religious knowledge through translated sources, the internet, and attend recitations in a number of mosques or on television. However, they have the ability to package fresher and more modern religious messages, therefore there are many young Muslims like their da'wah method. As for example, James B. Hoesterey (2018), described Abdullah Gymnastiar (Aa Gym) as a celebrity ustadz who gained religious popularity among the Indonesian Muslim community. Aa Gym does not have a strict Islamic education background, but because of his ability to deliver da'wah that emphasize the importance of puring the heart (heart management) on television, he has gained enthusiasm among Indonesian Muslims.

Besides Gym, Felix Siauw is an example of a new preacher who is very popular among young Indonesian Muslims. Hew Wai Weng, (2018) has described Felix as an ethnic Chinese lecturer who actively disseminates his da'wah through social media. Similar to Gym, Felix also does not have a strict Islamic religious education background. $\mathrm{He}$ is an alumnus of Institut Pertanian Bogor (IPB). Yet, he is very popular among urban youth due to his experience as a marketing manager in Jakarta and mastery of mass communication. The description of the emergence of new preachers above shows that the ulama is no longer monopolizes the symbol of religious authority. The new preachers massively held pengajian and formed da'wah communities attended by young urban Muslims. Felix Siauw, for instance, formed a community called Yuk Ngaji spread over several cities in
Indonesia. In this context, in Yogyakarta, the Muslim youth communities are very numerous and diverse. They actively hold religious studies in mosques and other places. Young Muslims in the city attended this event. Therefore, this phenomenon shows the fragmentation of religious authority in Indonesia.

In contrast to the previous system, they do not have to join the formal religious education system such as Islamic boarding schools to get religious knowledge. At the same time, they can gain such knowledge through recitations in many places and social media. In addition, Islamic religious education is no longer monopolized by ulama or Islamic religious teachers in schools but is fragmented in a number of recitations disseminated by new religious practitioners. In addition, globalization has encouraged the emergence of modern communication technologies such as the internet, making it easier for young people to access religious knowledge through the media.

\section{Conceptual Framework}

Based on the above matters, research on the fragmentation of religious authority, especially concerning young urban Muslims in Indonesia, is essential to see the dynamics of the contestation of religious authority in urban public spaces that are more specific and fuller of modernization. Then this study will obtain an overview of why urban Muslim youth are actively involved in religious recitations, how their negotiations go beyond the symbols of traditional religious authority, and their way of using social media to access religious resources.

The preference of Yogyakarta as the research location was based on several considerations. First, the youth da'wah movement in Yogyakarta was very diverse and hybrid. Some youth da'wah communities were affiliated with the Islamic organization Muhammadiyah, while others were affiliated with Nahdlatul Ulama, and some were even affiliated with the two Islamic community organizations. Therefore, by choosing Yogyakarta, this study would obtain a complex picture of the fragmentation of religious authority. Second, Yogyakarta is a city of education that has a number of wellknown and diverse universities. Many students in Yogyakart a came from all regions 
in Indonesia. Therefore, choosing Yogyakarta as the research location would represent the religious expression of young Indonesian Muslims.

\section{RESEARCH METHOD}

In order to explore the research results in these two cities, this study used a sociological approach. A statement from Northcott, (2016) sociological approach examines the interaction between society and religion, in this case, religion and society as objects that intersect. A sociological society is a society that has characteristics, the nature of the interaction, mutual need, dependence, and creates cultures. Relationships with one another, dependence, mutual adjustment, and social structures are firmly embedded in providing a diversity of identities.

The sociological approach does not examine the truth of religious doctrine but looks at how Muslims understand Islam. Regarding how Islam was discussed in the sociological realm, daily practices, hybrid Muslim identities, and negotiations with popular culture and modernization. Then how Islam practiced by its adherents. This is in line with Gilsenan's opinion quoted by Marranci, (2008) that the sociological approach in Islamic studies to explain the daily practice of a Muslim and the discourse of authority is constantly changing. This research was fieldbased research with data collection techniques: observations, interviews, documentation, and literature library sources.

\section{DISCUSSION \\ Popular Preacher and Fragmentation of Religious Authority}

According to (Greg Fealy and S. White, (2008), Monika Arnez \& Eva V. Nisa, 2016) the new religious authorities are religious actors who tend to present da'wah in a more popular and attractive religious atmosphere. They have fantastic storytelling skills in conveying their religious messages. While Turner, (2007) said that the new religious authority is a religious actor who does not have a qualified religious scientific background. They do not get religious education from formal education, such as Islamic boarding schools or madrasas, but secular (general) education. They also do not have a solid Islamic literature footing on classical Islamic sources such as Fiqh, Tafsir,
Al-Qur'an, and Sufism. However, being skillful at conveying (packaging) Islamic messages according to the wishes of modern society, their popularity has surpassed traditional religious authorities.

Turner's view above is in line with Echelman (2003) opinion, who argues that religious authority is always dynamic. Even with the development of technology and information, religious authorities are fragmented. Traditional religious authorities no longer control religious authority but new religious authorities. However, his religious popularity transcends traditional religious authority. Their da'wah messages are more acceptable to urban Muslim communities. Mara Einstein, (2008) called them as 'religious enterpreneur' or a popular preacher who presents religion in the form of a brand that fits the wishes of modern society. New religious actors in preaching use market logic in order to be well received by modern society. They appreciate the piety of the urban community according to a lifestyle closely related to consumption practices (Kailani dan Sunarwoto, 2019: 189)

However, they have the ability to package religious messages in a form that suits the tastes of modern society so that many young urban Muslims like their religious messages. For example, Ustadz Handy Bonny, or Ustaz Effie Evendi - a popular Indonesian Ustadz who has good storytelling skills in conveying religious messages among young people (Akmaliah, 2020; Hasan, 2018; Triantoro, 2019a). Coming from a new religious authority, the two popular Ustadz have fantastic storytelling abilities. Religious messages can be accepted well. They are good at offering religious messages according to the tastes of modern youth. They look modern yet religious. Ustadz Handy Bonny dan Ustadz Effie Efendi appreciate a lot of symbols of popular culture, a culture that is inherent in the identity of young people. For example, wearing flannel shirts, sweaters, jeans, and shawls (Triantoro, 2019b). They also used modern diction, such as "Dear, maafkan aku yang dulu", "Move One, Jalan Terus fi Jannati"; or used music, poster media, and creative poster video. This way, Islam would be easily accepted by young modern generation (Han, 2018; Triantoro, 2019b; Weng, 2018) 
Another case, Hoesterey, (2017) for instance, describes the figure of Abdullah Gymnastiar (Aa Gym) as a millennial preacher who has successfully gained popularity through combination of psychology, western management and Islam. He is both a preacher and a motivator. With this, the emergence of the new preachers above showed that the symbol of religious authority was no longer monopolized by ulama or a Kyai, who have qualified religious knowledge. The new preachers massively held recitations and also formed a da'wah community which was attended by young urban Muslims.

By looking back at the track, the city of Yogyakarta is the basis for the emergence of various popular youth da'wah movements. The da'wah movement in this city has developed well. Various religious organizations and youth da'wah movements in Yogyakarta during the last five years experienced a significant increase. In addition, the emergence of the da'wah movement also impacts the emergence of new authority figures initiated by the da'wah movement. For example, the Teras Da'wah movement is a da'wah social movement that is quite popular among young Muslims.

Almost all of the congregation of Teras Da'wah were young people. They looked very gaul and modern. Based on the author's field study at Teras $D a^{\prime} w a h$, they were very enthusiastic about participating in Teras Da'wah Islamic studies delivered by Ustadz Teras Da'wah. In groups, they came to the Teras Da'wah, listening to the pengajian delivered by the Ustadz of Teras Da'wah.

If their identity is traced, it is found that they come from various backgrounds. Consisting of young students, college students, street children, thugs, activists, and professionals. Their different identities united them as one even though they come from different backgrounds. They looked very compact. Ukhuwah Islamiyah between them was very loyal. This can be seen from the da'wah slogans with advice 5 and 6 , which were packaged in the form of poster media and uploaded through Teras Da'wah social media, as shown in pictures 1 and 2 (bekal nasehat 5 dan 6, 21 Februari 2020).

The dakwah slogan explains the importance of appreciating differences. Differences are not a separator or a barrier, but rather become unifier with one another, also complement one another. Differences become reinforcement between fellow congregations. In contrast, congregations can complement each other. From these provisions, a solid congregation was created.

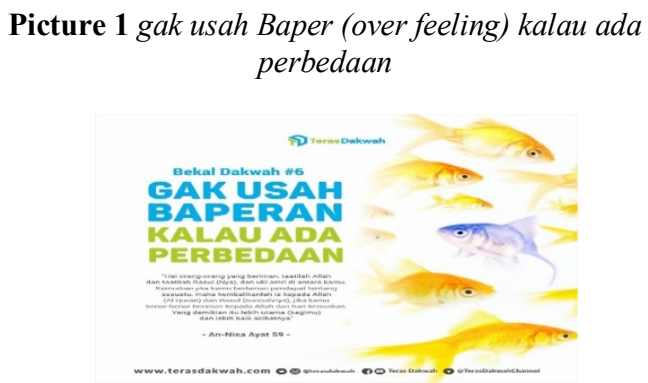

Picture 2 jangan merasa saleh berburlah

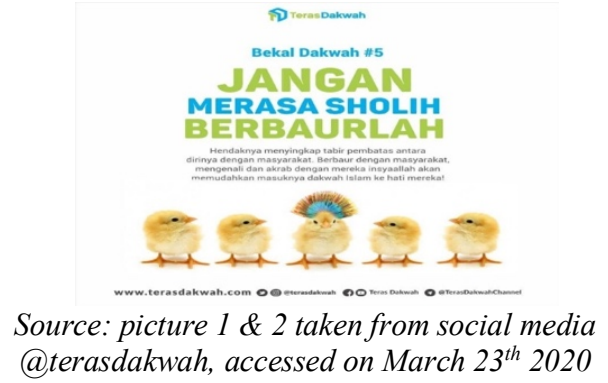

Then, most of the Ustadz of Teras Da'wah were a group of Ustadz with new religious authority backgrounds. As explained by Zaman, the new religious authorities are religious practitioners without a solid basis of Islamic literature, which is classical Islamic sources. They learnt Islam from the internet, social media, translated books, and lectures at mosques and television. However, even so, they mastered stunning marketing and storytelling techniques. In conveying Islamic messages, these modern Ustadz with extraordinary storytelling abilities amazed the audience by their performance.

In line with the field study that the researcher found regarding various backgrounds, even though the basis is not solid, but the preachers of Teras Dakwah employed good storytelling techniques in conveying religious messages, such as wearing clothes that looked gaul and using symbols of popular culture and languages. That way, the young people of the Teras Da'wah congregation were interested in Islam. The gaul appearance, captivating storytelling, humor, that made young Yogyakarta Muslims interested in Islam; therefore, they choose Teras Dakwah - as a fun and exciting place to study. 
Some figures of well-known Ustadz of Teras Dakwah among the Muslim youth of Yogyakarta were Ustaz Awan Abdullah, Ustaz Zaki Ahmad Rivai, Ustaz Fatan Fatanstik and Ustaz Kang Fredo. These ustadz were actively perform in the pengajian at the Da'wah Terrace. It was clustered in religious studies programs, such as the topic of hijrah, love, ta'aruf, youth, rebahan (laying down), entrepreneur, media, Islamic history and civilization, and Baitul Maqdis. As for example in "Sabar Ya Sayang Ini Ujian". then "Hijrah Total", "Generasi Mucin dan Bucin", "Nikah Ambyar Gara-Gara Salah Prinsip", "Menguak Seputar Baitul Maqdis", dan "The Bettle of Uhud" (see Instagram terasdakwah, 21 Maret 2020). The titles of the da'wah were managed by the Ustadz, who have their respective classifications of study topics. Ustadz Awan Abdullah, for example, is an expert on the theme of ta'aruf or romance. Then Ustadz Zaki Ahmad Rivai is an expert with youth and their laying down, and so on.

These Ustadz had an attractive da'wah packaging. They were very professional in their respective fields of expertise. They also were great in the commercialization aspect and as the da'wah agent in packaging the Islamic message which is readily accepted by wider Muslim community. Packing da'wah by understanding the da'wah's field then makes the da'wah practitioners accepted by a broader market. In addition, the appearance of the da'wah, which was attractive, gaul, and fresh, made the da'wah practitioner favored by the congregation, especially young people. Ms.Ani as the informant in this research said that:

"Saya suka mengikuti pengajian program rabu malam Teras Dakwah karena ustaz-ustaznya yang gaul, terutama Ustaz Abdullah Awan S. Pj. Saya menyukai kajian pra nikah yang diisi oleh ustaz Abdullah Awan S. Pj karena sejalan dengan kehidupanya. Saya juga masih menyandang status singgle (sendiri) yang memerlukan sosok pemimpin (suami) yang bisa membimbing hidup saya. Oleh karena itu, bekal pengajian ta'aruf sangat saya butuhkan untuk bekal nikah. Selain pesan-pesannya yang cocok, juga penyampaian (storytelling) dakwah Ustaz Awan Abdullah mudah dicerna, humoris dan asyik, sehingga banyak perempuan-perempuan (seperti saya) mengidolakan sosoknya" (Ani, 20 Januari, 2020, di Kota Gede).

In English:

"I like to take part in the pengajian of the Teras $D a^{\prime}$ wah on Wednesday night program because of the
Ustaz who is gaul, especially Ustaz Abdullah Awan S. Pj. I like the pre-marital study which is brought by Ustadz Abdullah Awan S. Pj because it is in line with his life. I am also in a single stat us (alone) who need a leader (husband) who can guide me in this life. Therefore, I really need the provision of ta'aruf for marriage. In addition to the appropriate messages, the storytelling of Ustaz Awan Abdullah's da'wah is easy to comprehend, humorous and fun, so that many women (especially me) idolize his figure" (Ani, January 20, 2020, in Kota Gede)".

Through the above informant's description (Ms. Ani), she likes Ustaz Abdullah Awan because of several considerations, especially that he was single. She must prepare provisions for the marriage. Then, she prefered Ustaz Abdullah Awan because the religious messages conveyed by Ustaz Awan were packaged in a fun way. The language was easy to comprehend, used a lot of popular languages, flexible with the context of youth culture, humorous, and fun. Through this consideration, she prefered Ustaz Awan's study at the Teras Da'wah.

The same thing was also conveyed by other person who like Ustaz Awan, Mbak Eni said:

\begin{abstract}
"saya juga masih menyandang status single (belum menikah). Saya sangat menyukai kajian Pra-Nikah yang diisi oleh Ustaz Awan Abdullah. Alasannya, selain penyampaian dakwahnya yang humoris, asyik dan kekinian, juga karena tema tersebut sesuai dengan kebutuhan saya untuk mempersiapkan bekal menuju jenjang pernikahan. Saat mengikuti kajian di Teras Dakwah, saya juga melibat berbagai anak muda disekeliling saya antusias pengikuti pengajian Ustaz Awan Abdullah Teras Dakwah. Saya mengaku sering bertemu dengan anak-anak muda Muslim lainnya yang berasal dari latar belakang sosial yang berbeda. Walau demikian kami menikmatinya" (Eni, 23 Januari, 2020, di Kota Gede).

In English:

"I am also still single (not married). I like the PreMarriage study, which Ustaz Awan Abdullah fills. The reason is, in addition to delivering his preaching, which is humorous, fun, and contemporary, it is also because the theme is in accordance with my needs to prepare provisions for marriage. While participating in the study at the Da'wah Teras, I also involved various young people around me who enthusiastically participated in the recitation of Ustaz Awan Abdullah's Teras Da'wah. I admit that I often meet other Muslim youths who come from different social backgrounds. Nevertheless, we enjoyed it" (Eni, January 23, 2020, in Kota Gede).
\end{abstract}

Besides Ustaz Awan Abdullah, there is also other popular Ustaz such as Ustaz Zaki Ahmad Rivai, known as Bang Zaki, who has amazing Islamic storytelling abilities. $\mathrm{He}$ 
looked very gaul and cool. In his Islamic lectures, he delivered many lectures on the themes of youth and laying down. He is very familiar with the popular languages of young people's dictions. He gave a lot of motivation to the congregation about the importance of exploring the potential of young people to build Islamic civilization. He says "umat Islam saat ini harus bangkit, kita berjalan sesuai dengan keahliannya masing-masing. Tak harus melalui ceramah, namun menyesuaikan dengan bidang keahlian kita (Teras Dakwah lectures, January 15, 2020 in a theme "Pemuda Rebahan").

The same thing was conveyed by Kang Iqbal Fais. He is the host of the TD Podcast media program (Podcast Teras Da'wah). In sharing messages, he gave a lot of motivation to the Teras $D a^{\prime}$ wah congregation about the importance of Muslims to maximize the potential of each individual in facing the challenges of da'wah. Because for Kang Iqbal, Muslim youth must focus on their abilities (skills), each potential in each individual. The extent to which the ability of da'wah is in accordance with his expertise.

In line with Ustaz Zaki and Kang Iqbal, Kang Rizki also conveyed da'wah messages to the congregation. He instilled about the importance of hijrah at a time when a moral crisis occurred among young people. In his tausiah message, he told of his life's migration journey. He told that he was in a motorcycle gang in the days before the move, liked to fight, race until he was in and out of iron bars (prison). The story of his journey, which is considered far from Islam, made Kang Rizki emphasize the importance of the younger generation to improve themselves immediately. Before it was comfortable to be revoked, then immediately to emigrate. From the storytelling of Kang Rizki's hijrah journey, he is now a good Muslim.

Presenting da'wah in the above ways, such as motorcycle gangs, going to prison, getting out of bars, made young people like Kang Rizki's lectures. The congregation was very enthusiastic about participating in the study organized by the Ustaz Teras Da'wah. This is because starting from selecting popular language dictions, symbols of popular culture, joining the motorcycle gang community, and getting involved in juvenile delinquency and fights. Thus, the clerics of Teras Da'wah became the favorites of the congregation.

\section{Muslim Youth Pengajian and Authority Fragmentation}

The growth of the $d a^{\prime}$ wah movement in various big cities in Indonesia has influenced changes in the orientation of Islamic literature, especially regarding the fragmentation of religious authorities. This fragmentation of informal education occured because of the growth of various da'wah movements in various cities. Young urban Muslims no longer learn religion through formal education, such as pesantren and madrasah, but shifting to da'wah communities, such as Teras Da'wah, which represents the desires of urban youth. The $d a^{\prime} w a h$ community is considered more open and flexible so that it quickly accepts changes from the outside world. They learn Islamic knowledge through pegajian of da'wah communities, starting from religion, culture, community, fun, and identity.

From a different point of view, urban youth were shifting more to the da'wah community caused by the learning model, teaching method, curriculum, approach, and packaging of da'wah. In the da'wah community, Islam was presented as more popular and updated, while in formal education was just the opposite. The lack of packaging causes young people to be more interested in the da'wah community. The emergence of the da'wah community also affects the fragmentation of religious authority among urban Muslim youth. On the one hand, it also shifted the role of formal education religious authorities. The role of formal religious authorities became fragmented. Young people no longer thoroughly learn religion through madrasas or Islamic boarding schools but pengajian activities organized by da'wah communities or social-religious da'wah institutions.

More details on the causes of urban Muslim youth preferring the da'wah community over formal institutions will be explained. This began with Mas Aji, who joined the Teras Da'wah community two years ago. His interest in joining the pengajian was motivated by the Teras Da'wah pengajian activities, which were not usually carried out by other $d a^{\prime} w a h$ communities. For example, the concept of $d a^{\prime}$ wah studies resembles a cafe building, then provide coffee shops, multimedia rooms, music, films, and uses social media. 
According to Mas Aji, the symbols of popular culture above were in line with his youth identity. He felt comfortable with the pengajian of Terrace Da'wah. This was because Teras Da'wah appreciates the identity of young people well. Mas Aji got space to be still able to appreciate his popular culture. Teras Da'wah was considered a distinctive da'wah movement, which can bridge the symbols of popular culture with piety and Islam.

Unlike formal education, which looks rigid, the da'wah community is considered to appreciate symbols of popular culture. This is under Mas Aji's desire to be enthusiastic about attending the Teras Da'wah lectures because it was considered in line with his youth identity, which is modern, gaul, and religious (Aji, February 20, 2020, at Teras Da'wah). With this, he felt compatible with the da'wah carried out by Teras Da'wah, how Teras Da'wah supplies in religion according to the wishes of young people, which was open to modernization and youth culture, and accepting input from the outside world.

For example, as in figure 3. The picture is a form of appreciation for Teras Da'wah for the symbols of youth popular culture. In recent years, coffee culture among young people has experienced a trend. Even coffee means a time to hang out and is part of the lifestyle of young people. They spend time to have coffee cult ure as part of their daily life, starting from fashion, hanging out, free time to assignments.

Linda Herrera \& Asef Bayat Bayat, 2010) said youth were largely influenced by global and local conditions. Therefore, the cultural strength of young people is considered as a model for nation-building. They cannot be equated with before, namely, people who are above their age (adults). They have an open and broad imagination in collaborating between his youth, identity, religion, and cult ure. They imagined adjusting to the cultural context of young people. By paying attention to the youth aspect, young people now take a strategic place in politics and culture in modern society (Herrera \& Bayat, 2010; Triantoro et al., 2019).

Meanwhile Hasan, (2018) said that the identity of the youth of his life cannot be separated from his youth. The youth identity of young people will always follow the changing of times. They will seek the process of self-discovery, rediscovery of their identity (Hasan, 2018; Saputra, 2019). Modernization and globalization will be deeply ingrained in young people. Their identity is embedded in them. Therefore, they will form their identity according to the rediscovery.

In line with (Hasan, 2018; Nilan \& Feixa, 2006; Saputra, 2019; Triantoro et al., 2019) stated that The identity of young people will continue to experience a process (selfconscious invention), namely the discovery of self-awareness and rediscoveries. In both of these processes, young people's identity will be influenced by the environment, identity, and self-negotiation. Bebedict R. O'G Anderson (2006) referred to as an 'imagined community'; they struggle with a global identity. They explore and interact with global identity values (Triantoro et al., 2019). They are not only involved in their community but at the same time also join other communities. They are connected globally, culturally, and on social media, which is closely related to the identity of Muslim youth nowadays.

Same thing also delivered by $\mathrm{S}$. Bamualim, Shaidar dan dkk., 2018), that the identity of Muslim youth, apart from leading to new consumption (such as environmentally friendly products, such as halal cosmetics, music, and clothing) on the other hand also raises new Islamic views, such as the proximity of Muslim youth to recitation communities. They were getting closer to Islamic activities. They were increasingly religious, gaul and modern. The Teras Da'wah community took elements of modernization and globalization such as cafes and hanging out to make people interested in Islam.

Understanding the Islamic needs of young people made young Muslims in Yogyakarta interested in da'wah from Teras Da'wah. Teras Da'wah adapted its da'wah to aspects of youth, culture, fun, and youth identity. This aspect was the power of the Teras Da'wah to influence the congregation to be more interested in Islam. The congregation will be more open-minded by viewing Islam as a flexible, anti-mainstream religion, which can adapt to the conditions of the times. The interest of Muslim youth in the symbols of popular culture became a consideration for the religious teachings to be packaged in an attractive, modern, and contemporary way. In the term of Einstein, (2008), Kailani, (2019) 
known as 'supply side religion' namely a religious authority that presents a religion that is in accordance with the wishes of modern society. In this case, the Da'wah Terrace presents religion through the culture of nongkrong (hanging out), starting from the cafe's design, the arrangement of the place, the interior, and other elements. It was presented between modernization, youth culture, and identity packaged into one.

Unlike Aji, Haqi was impressed with Teras Da'wah because Teras Da'wah sold merchandise products, such as t-shirts, sling bags, sweaters, shirts, beanies, and stickers. Such fashion products were very relevant to Haqi's youth identity, looking attractive, slang, and modern. Teras Da'wah merchandise makes Haqi feel that his identity has been appreciated. So he chose the Teras Da'wah as a fun and enjoyable place to study (Aji, February 22 2020, in Teras Dakwah).

Meanwhile, Khair appreciated the Teras Da'wah recitation because Teras Da'wah could embrace all groups. Regardless of where the identity comes from. The Da'wah Terrace embraces all worshipers. The difference for the Da'wah Terrace is not the main thing; the main thing is ukhwah Islamiyah. This unified the congregration even with different background. Different identity backgrounds made Khair interested in the da'wah concept promoted by Teras Da'wah. It is because he felt comfortable with the Teras Da'wah, so he made his choice to the Teras Da'wah.

Another reason for Teras Da'wah congregations for choosing the pengajian over formal education (madrasah and Islamic boarding schools) was because of its current da'wah programs. Mr. Dwi, for example, he was interested because Teras Da'wah has exciting programs. These programs include: Ngaji Teras, Ngaji Qohwah (Qopi Dakwah dan Ukhwah), Ngaji Entreprenuer, Ngaji Multimedia, Camping, Futsal, Outbound, Touring dan Traveling" (Dwi, February 20, 2020, in Teras Dakwah). These programs were packed in popular culture that is closely related to youth interests, such as enjoying coffee, nongkrong, traveling dan camping. Through this program, Dwi became interested in the pengajian of Teras Da'wah. Teras Da'wah was judged according to Dwi's youth expression, where the elements of popular culture were well appreciated by Teras
Da'wah. Until finally he decided to become the administrator of the Teras Da'wah. Similar to Dwi, Mr. Rifki said that:

\begin{abstract}
"Jika di pendidikan formal dianggap terlalu monoton seperti sistem pendidikanya yang terlalu kaku. Mulai dari ngaji sorogan, hafalan kitab, latihan kultum, dan seterusnya. Sehingga programnya tidak relevan dengan kehidupan anak muda saat ini. Sedangkan di komunitas dakwah sangat relevan, yang mana Islam selalu mengikuti tren kehidupan anak muda, seperti dorongan untuk hijrah, sekolah kilat pra nikah (ta'aruf), pesantren kilat, sharing-sharing santai (nongkrong), camping, entrepreneurship, media, festival musik, hapus tato, dan film" (Rifki, 16 Januari 2020, di Teras Dakwah).

In English:

"If formal education is considered too monotonous, the education system is too rigid. Starting from sorogan recitation, book memorization, concise da'wah exercises, and so on. Thus, the program is not relevant to the lives of young people today. Whereas in the da'wah community is very relevant, where Islam always follows the trends of young people's lives, such as the urge to hijrah, short-term pre-wedding schools (ta'aruf), short-term boarding schools, casual sharing (nongkrong), camping, entrepreneurship, media, music festivals, tattoo removal and movies" (Rifki, January 16, 2020, in Teras Dakwah).
\end{abstract}

Based on the arguments of the informants of the Teras Da'wah congregation above, it shows that the congregation chose to learn Islam in the Teras Da'wah because they could appreciate the Islamic culture of young people. Terrace Da'wah is able to bridge the piety, fashion, lifestyle, modernization and globalization. Packaging of a modern, contemporary da'wah program according to Bahasoan, (1985) is a contemporer da'wah movement. He said that the contemporary da'wah movement is characterized by Islamic programs covered in more popular packages (Bahasoan, 1985).

In addition, according to Ahmad in Ahmad Rosyad, (2006) that contemporary Islamic movements are characterized by their acceptance of aspects of modernity and technological development (Rosyad, 2006). While Najib Kailani, (2012) said that contemporary da'wah is one of a kind that negotiated with popular culture, such as novels, magazines, music and films. This kind of da'wah packaging will be more accepted by young urban Muslims. Thus, the young Muslims of Yogyakarta prefer to learn through Teras Da'wah rather than formal education because the programs were considered more representative of young people needs. 


\section{Social Media and Religious Authority Fragmentation}

The popularity of religious authorities today cannot be separated from the new media. New media ushered in new religious authorities to become popular preachers. (Turner, 2007) said that the new religious authority became popular thorugh the new media. The new media have ushered in new religious authorities to become preachers who are favored by the urban community. Even its popularity trumps traditional religious authorities. The popularity of the new religious authorities skyrocketed. Meanwhile, traditional religious authority is increasingly being eroded by new religious authorities. Thus, the fragmentation of religious authority led to the loss of the Ulama monopoly. The consequence is the birth of a 'new religious' authority.

On the other hand, the new religious authority also has a captivating storytelling skill. Although they do not have a strong foothold in Islamic literature, the storytelling skill attracted the attention of many people. So that religious messages could be well received by the urban community because in line with the wishes of the urban community.

The same thing also implied by Einstein, (2008) who said that the new religious authorities had the ability to package da'wah properly. The packaging of the popular storytelling attracts the urban community. They are more accurately referred to as selfhelp (or teachers) instead of preachers (Howell, 2012) or "smiling preacher" capable of understanding the needs of modern society who good at conveying religious messages that suit the tastes of contemporary society (Kailani dan Sunarwoto, 2019).

While Francois Gautheir et al., (2013) said that televangelists act as 'religious entrepreneur, namely presenting religion in the form of packaging in accordance with the wishes of modern society. In another view, it is referred as 'supply-side religion', which is to present as many religions as possible in a form that suits the tastes of modern society. Thus, they would embrace religion. (Kailani dan Sunarwoto, 2019).

Some popular Ustadz who have gained popularity through social media include Ustaz Felix Shiau, Ustaz Handy Bonny, and Ustaz Effie Efendi. The three preachers gained religious popularity through new media. The fans are dominant from young people. The packaging of religious messages is considered to be able to adapt to the wishes of urban youth.

The same thing happened to Ustadz Teras Da'wah. Some of the Ustadz such as Ustadz Awan Abdullah, Ustaz Zaki Ahmad Rifai and Ustaz Fatan F. Ustaz Awan Abdullah, S. Pj (partner Specialist). He was trusted by Teras Da'wah to fill a special religious study on the themes of 'love', 'premarriage', 'marriage' and 'romance'. As in the titles "Nikah Amnyar Gara-Gara Salah Prinsip", "Aku Cinta, Maka Kamu Kujaga", dan Gerasi Micin-Bucin (Misqin Cinta dan Butuh Cinta" (see Instagram terasdakwah, February 20, 2020)

Next, Bang Zaky A. Rifai. He specializes in studying discussions on the theme of youth, cool people around the Prophet, and association. Unlike the case with Ustaz Fatan Fantastik, whose expertise in the field of Islamic history studies. In contrast to other Ustaz, Ustaz Fatan Fantastik is packed with gaul, humor, and popular languages in delivering his religious lectures. His lectures were easy to understand for young children. His religious lectures are similar to storytelling preachers (Saputra, 2020).

Besides storytelling, he also likes humor. So that religious messages were not considered monotonous. His humorous and fun presentation made his lectures liked by the Teras Da'wah congregation. His humorous religious message made the atmosphere felt flexible, many worshipers laughed out loud, because of his charm, fun and entertaining preaching message (Saputra, 2020).

Ustadz Teras Da'wah appearance was gaul and modern, following a young man style. They wore jeans, flannel shirts and tshirts. The gaul fashion they wear reflects a flexible and open-minded Ustaz. Fealy, (2008) said the new religious authorities were more likely to convey Islam in a more modern way. In contrast, the old authority is more traditional. The da'wah of the new religious authority is well-received by modern society.

Kailani dan Sunarwoto, (2019) say the media creates celebrity culture, that is, those that are based on celebrity culture (celebrity-based culture) or those who centered on the fame of people created by the media (media-generated fame). They are religious people born from celebrity culture 
who joined the media industry. It was this culture that makes Ustaz-Teras Da'wah popular. Their popularity increased when social media became a medium of da'wah. The combination of celebrity culture with new media gave birth to a new authority discourse, celebrity culture.

As the writer has stated in the previous section, the development of communication technology has changed the life of the Muslim community. Eichelman \& Anderson, (2003) argues that the new media fragmented religious authority. The emergence of new preachers who are popular among young people due to their ability to convey religious messages on social media. Instead, social media itself, as said by Mingyi Hou, can provide celebrity culture.

Social media has changed the religious practices of the Muslim community in Indonesia which previous scholars have shown. Nadirsyah Hosen, (2008) for example, he showed how the Muslim community has begun to shift from previously consuming fatwas in traditional forms through Islamic organizations such as Nahdlatul Ulama, Muhammadiyah, and the Indonesian Ulema Council to the forms of fatwas available on social media or in his term, 'googling kyai.'

In addition to the media that provide discourse on new religious practices, this condition is also supported by a number of da'wah communities that offer religious knowledge through social media to target young Muslims. The Yogyakarta Da'wah Terrace also carried out this matter. Mr. Ilyas, one of the Teras Da'wah media team said that to attract the enthusiasm of today's young people in participating in da'wah events, they must use popular media, a social media. “.......TD kui iso dikenal uwong akeh yo karena mediane, lah awake dewe kui harus iso manfaatke media, ben iso narik jamaah cah enom Jogja. " (.....TD it can be known by many people, because of the media, so we must be able to use the media as well, in order to attract Jogja youth) (Ilyas, January 10, 2020, in Teras Dakwah).

Teras Da'wah used various media to promote their da'wah such as Youtube and Instagram. On YouTube, Teras Da'wah promoted their da'wah such as the Quran recitation event entitled Panik Ga? Panik Ga? Enggaklah, Kan Beriman delivered by Mas Zaky Ahmad Rivai, while Aya Sophia dan
Nusantara delivered by Ustaz Salim A. Fillah, and other Teras recitation events. Then the fun Koran recitation event entitled Tafsir Tarawih delivered by Ustadz Qaem Aulassyahied. The latest program initiated by Teras Da'wah was the Ramadan Superbooster entitled Yang Tua Yang Butuh Pahala, Shof Berkemajuan, Mogok di Tengah Jalan, and many other (see terasdakwah, February 25, 2020).

Those programs were watched by hundreds of audiences. Such as, Ngaji Teras (recitation) entitled Panik Ga? Panik Ga? Enggaklah, Kan Beriman presented by Mas Zaky Ahmad Rivai, until May $1^{\text {st }} 2021$, this show has been viewed 305 times. Then the Youtube da'wah entitled Aya Sophia dan Nusantara has been watched by more than 8 thousand viewers. Another program, the Ramadan Superbooster program entitled Yang Tua Yang Butuh Pahala, Shof Berkemajuan, this program has been watched about 160 times (terasdakwah, February 26, 2020).

Just like on Youtube, da'wah of Teras Dawah on Instagram also shows the same thing. They posted a number of da'wah studies filled by several Ustaz such as the da'wah entitled "Rebutan Warisan Nabi Saw" by Ustaz Feri Septianto. This post has over 2,403 views. Then post about "Ironi di Bulan Suci: Ngecrit sambil Ngabuburit? Boleh Gak?", this show has been watched more than 7,441 views (terasdakwah, February 26, 2020).

In addition to the da'wah videos above, Teras Dakwah also posted da'wah posters, such as the post on April 29, 2021, about breaking the fast. In the poster, Teras Da'wah promotes the prophet's hadith about the sunnah breaking the fast. Rasulullah SAW broke his fast with Ruthob (wet dates) before praying. If there is no Ruthob, Hbreaks his fast with tamr (dried dates), and if there is no such thing, He says with a sip of water). HR. Abu Daud.

In another poster, Teras Da'wah posted about the Sirah nabawiyah explaining how the Prophet (s) faced his da'wah's challenges. This story was packed with exciting pictures and short descriptions of the caption. This post received a positive response (like) of 306 likes.

Some of the posts above show that Teras Da'wah has facilitated young people to gain religious knowledge through social media such as Instagram and Youtube. This 
condition shows that the media, in turn, causes religious authorities and religious education to be fragmented. In order to gain religious knowledge, young people no longer have to go to an Ustaz or preacher and read religious matters through primary sources such as hadith and others. However, in turn, they can access it through social media. This phenomenon mainly occurs in upper-middleclass Muslim society, which has undergone modernization and globalization. They have easy internet access and can buy communication tools such as smartphones and others.

\section{CLOSING}

From the explanation above, the researcher conclude that the fragmentation of religious authority occurs among young Muslims. Few of them accessed religious knowledge, not through traditional religious authorities such as ulama, and directly read classical Islamic sources such as the Koran, hadith, the yellow book (Kitab Kuning), and others. The proliferation of recitations held in urban spaces in Indonesia filled with new ustaz (new religious authorities) and social media contributed to this fragmentation.

These activities are facilitated mainly by da'wah communities spread across major cities in Indonesia, including the Da'wah Teras in Yogyakarta. Teras Dakwah is active in holding recitations packed with youth popular culture. Their recitations are also filled by 'new' preachers who are adapting to the aspirations of young Muslims. In addition, they also use media such as Youtube and Instagram to promote their da'wah events and even use these media as a means of preaching. This, in turn, opens up opportunities and facilitates young people to gain religious knowledge 'instantly' without having to visit an ustaz and even enlist to Islamic religious education such as Pesantren (islamic boarding school).

\section{ACKNOWLEDGEMENT}

Thank you to the editorial team of the Al-Qalam journal, Makassar Religious Research and Development Agency, who has accepted this article.

\section{REFERENCES}

Akmaliah, W. (2020). The Rise of Cool Ustadz: Preaching, Subcultures, and the Pemuda Hijrah Movement. In N. Saat \& A. N. Burnahni (Eds.), The New Santri: Challenges to Traditional Religious Authority in Indonesia (pp. 239-257). ISEAS Yusof Ishak Institute.

Arnez, M., \& Nisa, E. F. (2016). Dimensions of Morality: The Transnational Writers' Collective Forum Lingkar Pena. Journal of the Humanities and Social Sciences of Southeast Asia and Oceania, 174(4), 1-30. https://doi.org/10.1163/2213437917204003

Bahasoan, A. (1985). The Islamic Reform Movement: An Interpretation and Criticism', Prisma: The Indonesian Indicato.

Bamualim, Chaider S. dan dkk. (2018). Kaum Muda Muslim Milenial:

Konservatisme, Hibridasi Identitas, dan Tantangan Radikalisme. Pusat Kajian Agama dan Budaya UIN Syarif Hidayatullah.

Eichelman, D. F., \& Anderson, J. W. (2003). New Media in the Muslim World: The Emerging Public Sphere. In Indiana University Press. Indiana University Perss.

Einstein, M. (2008). Brand of Fiath: Marketing Religious in a Commercial Age. Routledge.

Fealy, G. (2008). Consuming Islam: Comodified Religion and Aspirational Pietism in Contemporary Indonesia. In G. Fealy \& S. White (Eds.), Ekspressing Islam: Religious Life and Politics in Indonesia (pp. 1-15). Institute od Southeast Asian Studies.

Gautheir, F., Woodhead, L., \& Martinainen, T. (2013). Gautheir, In Frncois Gautheir \& T. Martikainen (Eds.), Religion in Const umer Society: Brands, Consumers and Markets (pp. 1-26). Ashgate.

Han, M. I. (2018). Anak Muda, Dakwah Jalanan dan Fragmentasi Otoritas Keagamaan: Studi Atas Gerakan 
Dakwah Pemuda Hijrah dan Pemuda Hidayah. UIN Sunan Kaloijaga.

Hasan, N. (2018). Menuju Islamisme Populer. In N. Hasan (Ed.), Literatur Keislaman Generasi Milenial: Transmisi, Apropriasi, dan Kontestasi. Suka Perss.

Herrera, L., \& Bayat, A. (2010). Conclusion: Knowing Muslim Youth. Being Young and Muslim in Neoliberal Times: New Cultural Politics in the Global South and North, 355-364.

Hoesterey, J. B. (2018). Marketing Islam: Entrepreneueial Ethics and the of Chapitalism in Indonesia. Spring, 10, 114.

Hosen, N. (2008). nline Fatwa in Indonesia: From Fatwa Shopping to Goggling a Kiai. In Greag Fealy \& S. White (Eds.), Expressing Islam: Religious Life and Politics in Indonesia (pp. 159-173). Institute of Southeast Asian Studies.

Howell, J. D. (2012). 'Caling and Training': Role Inovation and Religious DeDeferentiation in Commercialised Indonesia Islam. Journal of Contemporary Religion, 28(3), 414416.

Kailani, N. (2012). Forum Lingkar Pena and Muslim youth in contemporary Indonesia. RIMA: Review of Indonesian and Malaysian Affairs, 46(1), 33.

Kailani, N. dan S. (2019). Televangelisme Islam dalam Lanskap Otoritas Keagamaan Baru. In N. Hasan (Ed.), Ulama dan Negara-Bangsa: Membaca Masa Depan Politik Islam di Indonesia (pp. 179-206). Suka Perss.

Marranci, G. (2008). Antropology of Islam. Breg.

Nilan, P., \& Feixa, C. (2006). Global Youth? Hybrid Identities, Prural Word. Routledge.

Northcott, M. S. (2016). Pendekatan Sosiologis. In P. Connoly (Ed.), Aneka Pendekatan Sosiologis. Ircisod \& LKIS.
Nurlaelawati, E., \& Muhrisun. (2018). Ulama, Negara dan Wajah Hukum Islam. In N. Hasan (Ed.), Ulama dan NegaraBangsa: Membaca Masa Depan Politik Islam di Indonesia (1st ed., pp. 95-134). PusPIDeP.

Rosyad, R. (2006). A Quest for True Islam: A Study of the Islam Resurgence Movement among the Youth in Bandung. ANU E Perss.

Saputra, E. (2019). Menelisik Radikalisme Gen Z Perempuan di Facebook. Islamica: Jurnal Studi Keislaman, 14(1), 103-130.

Saputra, E. (2020). Teras Dakwah, Agama dan Pasar. Idarot una, 3(1), 16-41.

Suhadi, \& Suseno, M. N. (2018). Ulama dan Negara-Bangsa dalam Survei. In N. Hasan (Ed.), Ulama dan NegaraBangsa: Membaca Masa Depan Politik Islam di Indonesia (1st ed., p. 18). PusPIDep.

Triantoro, D. A. (2019a). Ustaz Abdul Somad, Otoritas Karismatik dan Media Baru. In Tesis. UIN Sunan Kalijaga.

Triantoro, D. A. (2019b). Ustaz Abdul Somad: Ustaz Karismatik Dunia Digital. Omah Ilmu.

Triantoro, D. A., Saputra, E., \& Wahyuni, T. (2019). Mengelola Hibridisasi Identitas Anak Muda Islam: Studi Pada Lembaga Teras Dakwah di Yogyakarta. Jurnal MD, 5(2), 113-138.

Turner, B. S. (2007). Religious Authority and the New Media. Theory, Culture \& Society, 24(2), 117-134.

Weng, H. W. (2018). The Art of Dakwah: Social Media, Visual Persuasion and the Islamist Propagation of Felix Siauw. Indonesia and the Malay World, 46(134), 61-79.

Zaman, M. Q. (2002). The Ulama Contempory Islam: Custodians of Change. Princton University Perss.

Zulkifli, Z. (2013). he Ulama in Indonesia: Between Religious Authority and Symbolic Power. MIQOT: Jurnal IlmuIlmu Keislama, 37(1). 